\title{
RELIABILITY, SAFETY AND EXPLOITATION OF TECHNICAL OBJETS - ATTRIBUTES TO BE OUT OF ORDER OF MODERN CIVILIZATIONS
}

\section{NIEZAWODNOŚĆ, BEZPIECZEŃSTWO I EKSPLOATACJA OBIEKTÓW TECHNICZNYCH - ATRYBUTY FUNKCJONOWANIA WSPÓLCZESNYCH CYWILIZACJI}

\author{
Jerzy Lewitowicz ${ }^{1)}$, Stefan Rutkowski ${ }^{2}$, \\ Ryszard Tomaska $^{3)}$, Andrzej Żyluk ${ }^{1)}$ \\ ${ }^{1)}$ Instytut Techniczny Wojsk Lotniczych, ${ }^{2)}$ MS DEFENDER s.c., ${ }^{3)}$ BAE SYSTEMS \\ jerzy.lewitowicz@itwl.pl; ryszard.tomaska@baesystems.com; \\ stefan.rutkowski@poczta.fin; andrzej.zyluk@itwl.pl
}

\begin{abstract}
Civilization is a state of human society during a particular period of time, conditioned with the degree to which the humans are able to control the nature; the total of already collected material goods, means of production and exploitation, suitable skills (know-how), and social institutions. It is processes of exploitation of engineered objects and natural resources of the Earth that closely and directly relate the economy, safety (widely understood) and environmental protection. Nowadays, as the development of technology has become a hectic process, too little attention is paid to safety. People die. The above outlined considerations can be summarized in the form of the following conclusion: Exploitation is an area that covers the art of many and various activities. It is a philosophy that puts all the fields of knowledge together. Therefore, it should be considered a separate line of science.
\end{abstract}

Keywords: civilization, exploitation, safety

Streszczenie: Cywilizacja to stan rozwoju spoleczeństwa $w$ danym okresie historycznym, uwarunkowany stopniem opanowania przyrody przez człowieka; ogót nagromadzonych dóbr materialnych, środków umiejętności produkcyjnych $i$ eksploatacyjnych oraz instytucji spolecznych. To procesy eksploatacji urzadzeń technicznych i zasobów naturalnych ziemi ściśle wiąża ekonomię, bezpieczeństwo (szeroko rozumiane) $i$ ochronę środowiska. W szalonym rozwoju techniki za mato poświęca się uwagi bezpieczeństwu. Ludzie gina. Podsumowaniem powyższych naszkicowanych rozważań może być konkluzja, że: eksploatacja jest nauka zawierająca sztukę różnorodnych działań, jest filozofia skupiajaca wszystkie obszary wiedzy, a zatem powinna już zostać uznaną za dyscyplinę naukowa.

Stowa kluczowe: cywilizacja, eksploatacja, bezpieczeństwo 


\section{Wprowadzenie}

Niebywały poziom rozwoju współczesnej cywilizacji XXI wieku - rozwoju obiektów technicznych (urządzeń technicznych - UT) wymaga ich eksploatacji i systemów zaopatrujących: logistyki. Do najbardziej rozpowszechnionej definicji słowa „cywilizacja” [1, 6, 7] należy dodać zatem nowy fragment dotyczący obszaru działalności człowieka - eksploatacji. Definicja przyjmie brzmienie: Cywilizacja to stan rozwoju społeczeństwa $w$ danym okresie historycznym, uwarunkowany stopniem opanowania przyrody przez człowieka; ogót nagromadzonych dóbr materialnych, środków umiejętności produkcyjnych i eksploatacyjnych oraz instytucji społecznych.

Procesy eksploatacji obiektów technicznych i zasobów naturalnych ziemi ściśle wiążą ekonomię, bezpieczeństwo (szeroko rozumiane) i ochronę środowiska. W szalonym rozwoju techniki za mało uwagi poświęca się bezpieczeństwu, w tym bezpieczeństwu ludzi, którzy niestety giną. Nie wystarczy zaprojektowanie, skonstruowanie wyprodukowanie nowoczesnego np. statku powietrznego, jeżeli nie odpowie się z góry na pytania ekonomiczno-strukturalne: ile będzie kosztować eksploatacja, jaka będzie jego niezawodność, jakiej wymagać będzie organizacji eksploatacji, jakiego oprzyrządowania, jakich kwalifikacjach personelu do realizacji strukturalnych zadań $\mathrm{w}$ locie, jakiego systemu logistycznego? Działalności współczesnych społeczeństw w obszarze UT powinna przyświecać zasada myślenia eksploatacyjnego, która wyraża się najogólniej jako: uświadomienie, $w$ konkretnych uwarunkowaniach, konieczności działania wynikającego z rozumienia zasad $i$ prawidłowości rządzacych eksploatacja, ze wszystkimi tego skutkami.

\section{Cywilizacja techniczna}

Definicja pojęcia „cywilizacja” z lat sześćdziesiątych XX wieku brzmiała: Cywilizacja: stopień rozwoju społecznego i kultury materialnej osiagnięty przez dana formację społeczno-ekonomiczna [6]. W nowszym ujęciu definicji dodano właściwość umiejętności produkcyjnych: Cywilizacja - stan rozwoju społeczeństwa $w$ danym okresie historycznym, uwarunkowany stopniem opanowania przyrody przez człowieka; ogót nagromadzonych dóbr materialnych, środków i umiejętności produkcyjnych oraz instytucji społecznych [7]. I rzeczywiście współcześnie osiągnięto niebywały postęp w rozwoju urządzeń technicznych, które stały się nieodzownym krajobrazem codziennego życia współczesnych społeczeństw. Na rysunku 1 przytoczono przykłady kilku wybranych olbrzymich skonstruowanych i wyprodukowanych urządzeń technicznych, takich jak: statek na tysiące kontenerów, okręt wojenny - lotniskowiec, na którego pokładzie stacjonują dziesiątki samolotów, samolot pasażerski zabierający do tysiąca pasażerów. Diagnostyka medyczna wykorzystuje dziesiątki urządzeń technicznych, takich jak: tomograf, rezonans magnetyczny, aparat USG i wiele innych. Co jest wspólne dla takich urządzeń? - ich eksploatacja. To ich użytkowanie i utrzymywanie zdatności technicznej. 

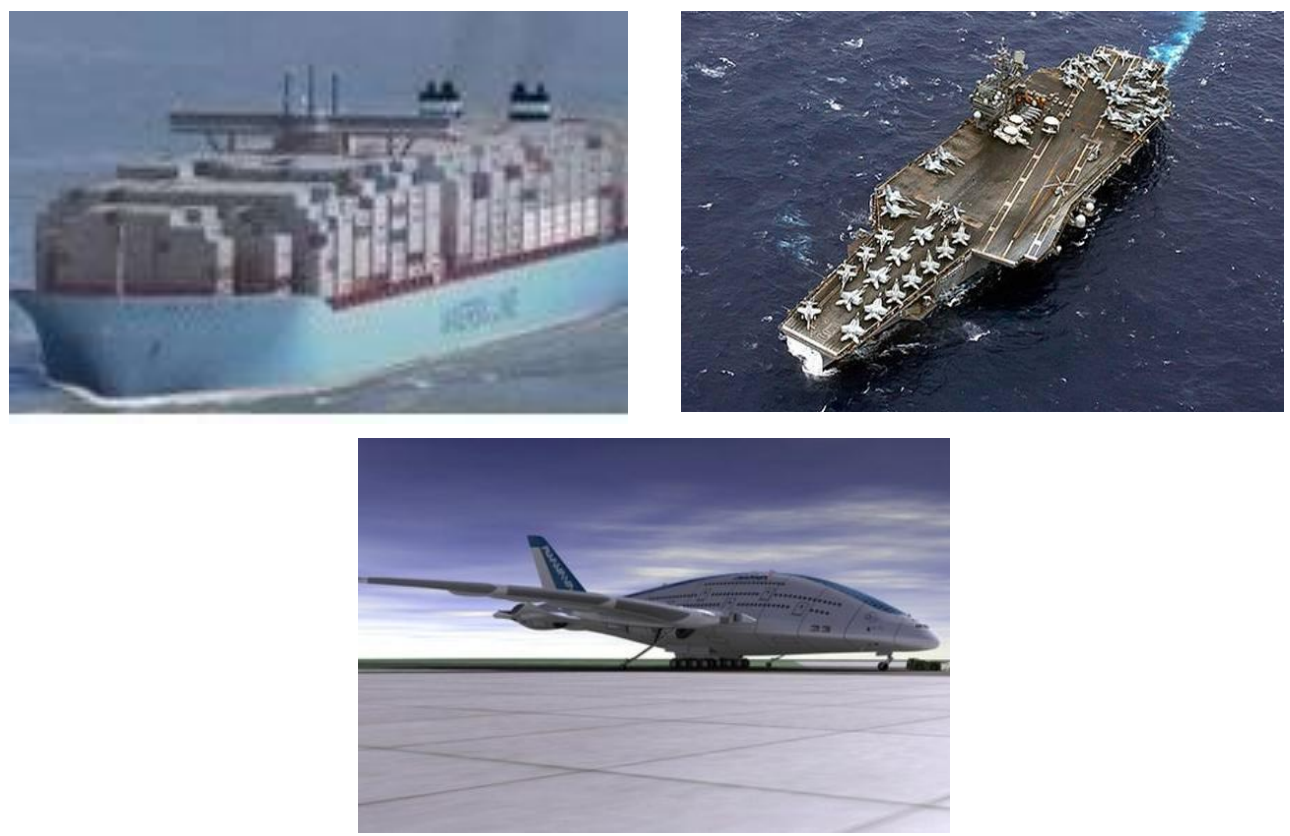

Rys. 1. Olbrzymie konstrukcje transportowe: kontenerowiec, lotniskowiec, samolot (fot. Internet)
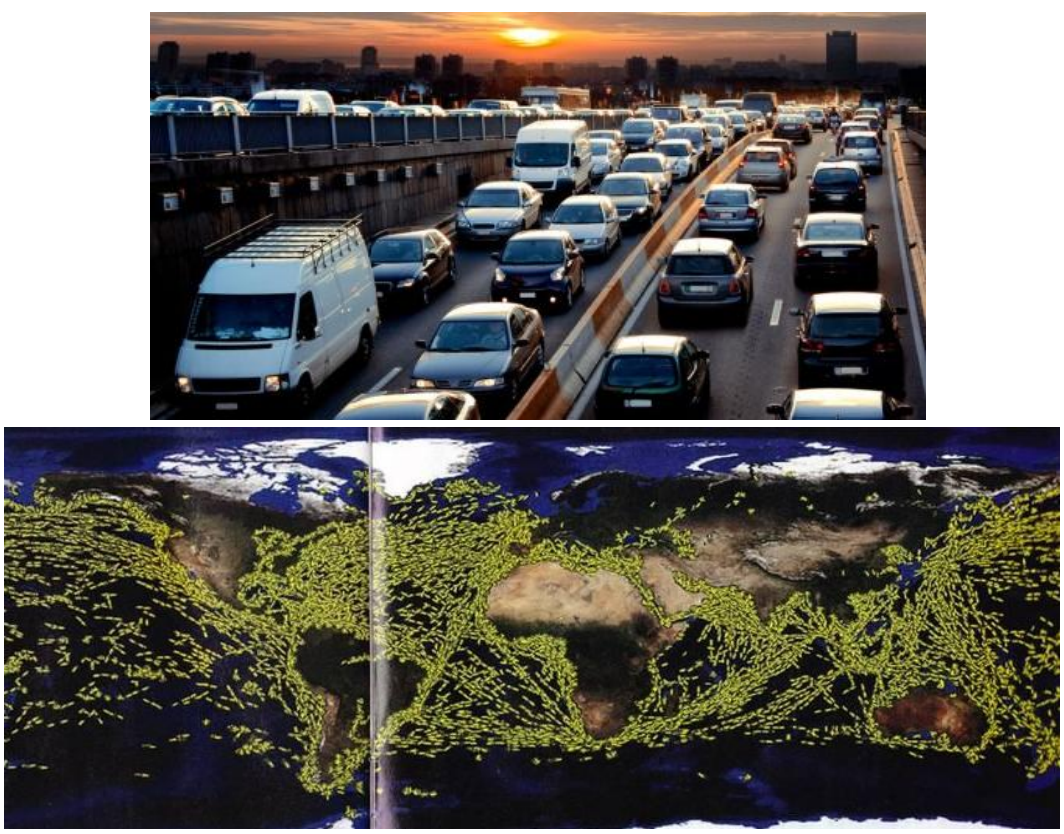

Rys. 2. Ruch samochodowy na autostradzie i lotniczy na kuli ziemskiej (fot. Internet) 
Na rysunku 2 pokazano przykładowo złożoność użytkowania dwóch środków transportu: samochodów i samolotów pasażerskich. Jakże złożone są trasy jazdy na autostradach i lotów. Jaka intensywność ruchu.

Wymóg gotowości technicznej do użytkowania i bezpieczeństwo w eksploatacji osiąga się poprzez redundancję zespołów i instalacji całego urządzenia technicznego. Co doprowadza do coraz bardziej złożonych układów konstrukcyjnych. Przykładem może tu być kokpit współczesnego samolotu wojskowego i pasażerskiego (rys. 3). Osiąga się obecnie wysoki stopień niezawodności i żywotności, tj. odporności na zakłócenia podczas użytkowania. Jak duża jest to odporność (żywotność) - np. samolotu - pokazano na rysunku 4. Mimo tak dużych uszkodzeń, zniszczenia fragmentu skrzydła samolotu pilot zdołał opanować zachowanie samolotu (miał do tego manewru dostateczną wysokość lotu) i wylądować. Złożone układy konstrukcyjne niestety generują uszkodzenia elementów, zespołów, instalacji, co wymaga działań eksploatacyjnych, zwanych odnową, przywracających pierwotne cechy użytkowe. Odnowa zapewnia utrzymanie zdatności technicznej urządzenia technicznego. Zatem, przytoczoną powyżej definicję pojęcia „cywilizacja” należy uzupełnić o nadzwyczaj ważny obszar działań współczesnych społeczeństw - o szeroko rozumianą eksploatację.
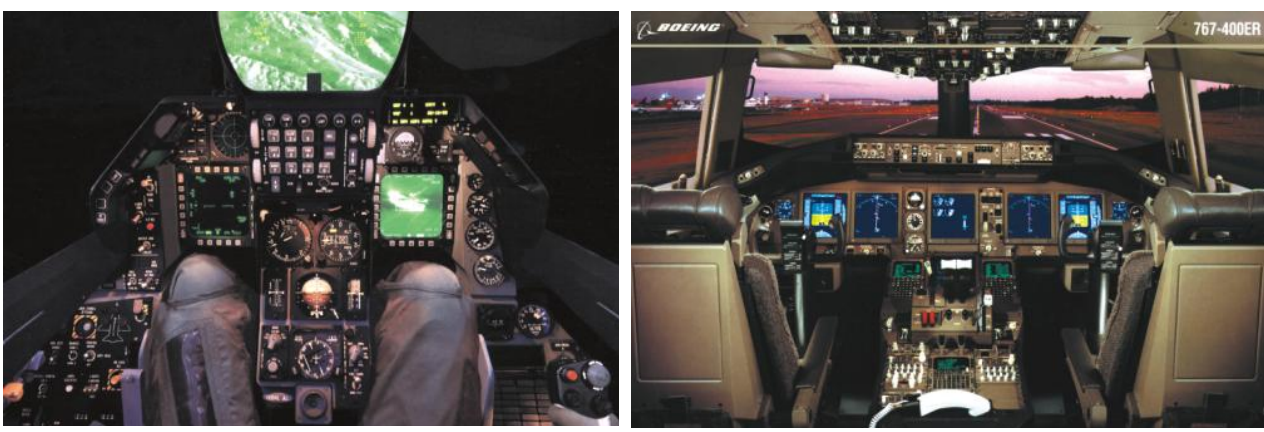

Rys. 3. Kokpit w samolocie wojskowym bojowym F-16 i pasażerskim B-767
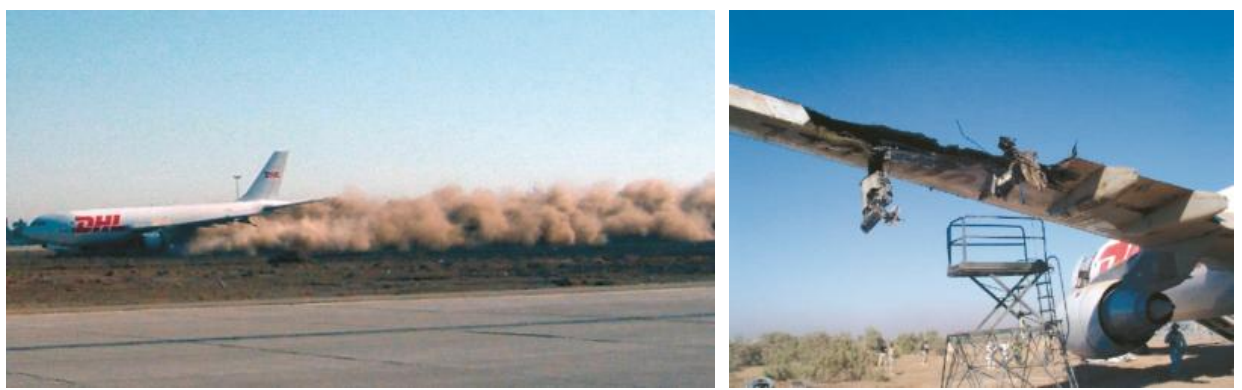

Rys. 4. Ladowanie samolotu A-300 z uszkodzonym skrzydtem 
Wówczas definicja ta przyjmie brzmienie: Cywilizacja to stan rozwoju społeczeństwa $w$ danym okresie historycznym, uwarunkowany stopniem opanowania przyrody przez człowieka; ogót nagromadzonych dóbr materialnych, środków umiejętności produkcyjnych $\boldsymbol{i}$ eksploatacyjnych oraz instytucji społecznych. To procesy eksploatacji urządzeń technicznych i zasobów naturalnych ziemi ściśle wiążą ekonomię, bezpieczeństwo (szeroko rozumiane) i ochronę środowiska. Ludzkość eksploatuje miliony samochodów, tysiące statków powietrznych, statków morskich i niepoliczalną dziś liczbę urządzeń technicznych (UT). Ale dlaczego giną ludzie?

\section{Eksploatacja urządzeń technicznych}

Eksploatacja obiektów technicznych to pojęcie, w którym mieszczą się systemy w stanie statycznym - systemy eksploatacji UT, i w stanie dynamicznym opisywane przez procesy eksploatacji UT, oraz zjawiska i procesy zachodzące w samym urządzeniu technicznym, wpływające na jego cechy użytkowe. Współczesna konstrukcja urządzenia technicznego musi być projektowana pod kątem spełnienia zarówno zakładanych parametrów technicznych, jak i eksploatacyjnych. Istotnym czynnikiem, jaki musi być brany pod uwagę, jest wieloletnia eksploatacja. Zakłada się wysoką niezawodność.

Spełnienie wymagań eksploatacyjnych wymaga zrealizowania odpowiedniej procedury optymalizacyjnej. W tym celu już na etapie projektowania UT powinno się opracować modele eksploatacji (strukturalny, fizyczny, matematyczny i informatyczny) [2]. Każdy z modeli bada się metodami symulacji, a następnie weryfikuje wstępnie w fazie badań prototypu i wstępnych badań eksploatacyjnych. Ostatecznym weryfikatorem jakości UT jest długotrwała eksploatacja w przyjętych strukturach systemów organizacyjnych. W tym też okresie istnieje możliwość i potrzeba dalszego udoskonalania procesu eksploatowania UT.

System eksploatacyjny $(S E)$ to złożony zbiór UT, załóg $(Z)$, logistyki $(L)$ powiązanych odpowiednimi relacjami $F$ ( $F$ - zbiór relacji pomiędzy elementami zbiorów UT, Z, L) zanurzonych w otoczeniu $(O)$, charakteryzujących się niezawodnością $\left(\mathrm{R}_{\mathrm{SP}}, R_{L S E}\right)$, gotowością $\left(G_{\mathrm{SP}}, G_{\mathrm{LSE}}\right)$, bezpieczeństwem $\left(B_{\mathrm{SP}}, B_{\mathrm{LSE}}\right)$ oraz wydatkami (kosztami) ponoszonymi na działania systemu. Można to zapisać w postaci zbioru, SE przy maksymalizacji niezawodności, gotowości i bezpieczeństwa UT i SE, minimalizując koszty $(K)$ [4]:

$\langle S E\rangle=\left\{\langle U T\rangle,\langle Z\rangle,\langle L\rangle,\langle F\rangle, O ; \max : R_{\mathrm{UT}}, R_{\mathrm{SE}} ; G_{\mathrm{UT}}, G_{\mathrm{SE}} ; B_{\mathrm{UT}}, B_{\mathrm{SE}} ; \min : K\right\}$

Szeroko rozumiane pojęcie „eksploatacja UT” przedstawia złożony dynamiczny proces powiązanych ze sobą procesów cząstkowych jak realizacja procesu użytkowania, eksploatacja techniczna itd. Pod pojęciem technicznej eksploatacji 
UT rozumie się procesy i działania mające na celu zapewnienie zakładanej gotowości, niezawodności, bezpieczeństwa.

Pojęcie to mieści w sobie także stany technicznej obsługi, remontu (ogólnie odnowy), magazynowania, transportu (ogólnie logistyki).

Realizatorem procesów eksploatacji w SE jest człowiek. Od poziomu jego wiedzy oraz podatności eksploatacyjnej UT (użytkowej, obsługowej, diagnostycznej, remontowej - zakumulowanej $\mathrm{w}$ procesie projektowania) zależą efekty ekonomiczne i bezpieczeństwo użytkowania UT.

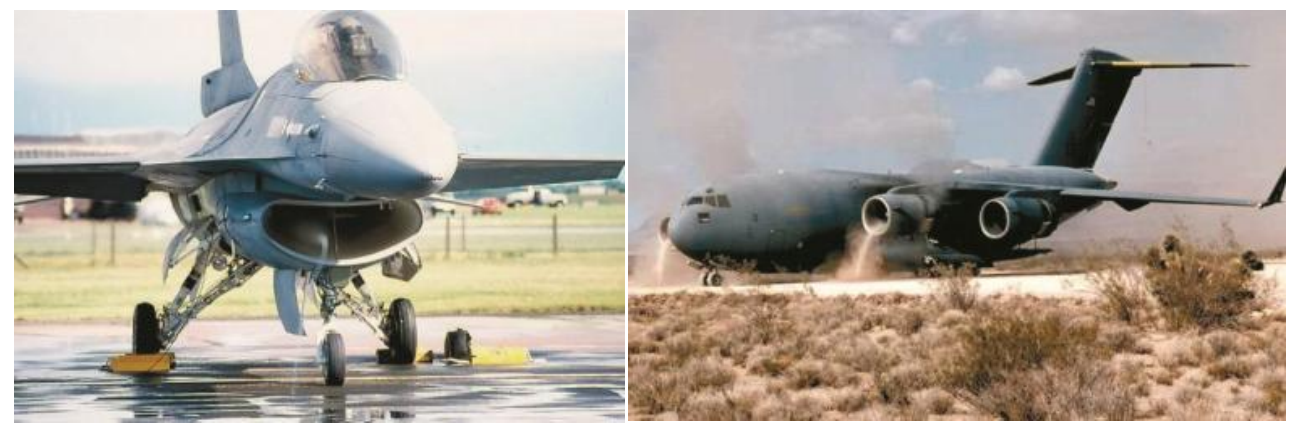

Rys. 5. Wiry, które zasysaja do silników ciała obce

Konstrukcje UT charakteryzują się obecnie znacznym jednostkowym obciążeniem konstrukcji często już wykonanych z nowych materiałów (kevlaru, kompozytów itp.), co pociąga za sobą - przy oddziaływaniu czynników cieplnych, mechanicznych i fizykochemicznych w czasie - znacznie intensywniejsze oddziaływanie procesów destrukcyjnych (zużyciowych, starzeniowych, zmęczeniowych itp.), skutkujących powstawaniem uszkodzeń. $\mathrm{Na}$ rysunkach 5, 6, 7 pokazano przykładowe uszkodzenia statków powietrznych wywołanych wirami zasysającymi ciała obce do silników odrzutowych, uszkadzające łopatki sprężarek i turbin, zmęczeniowe pęknięcie osi koła podwozia samolotu, destrukcję samolotu spowodowaną powstaniem drgań typu flatter.

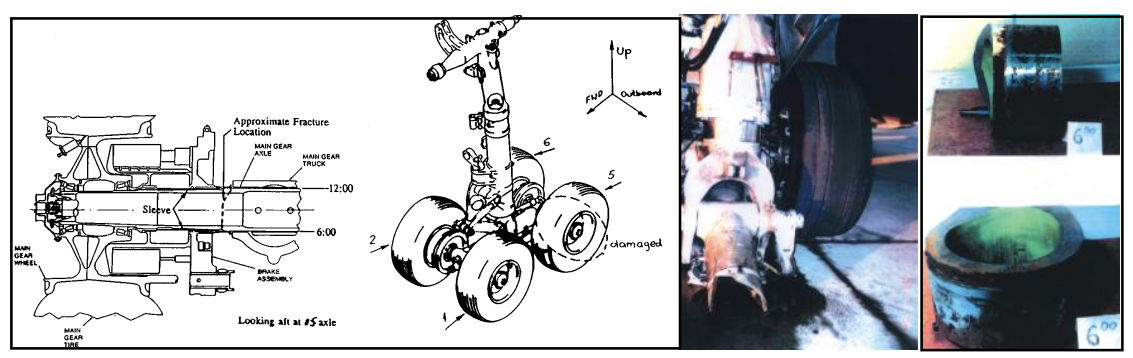

Rys. 6. Pęknięcie zmęczeniowe osi koła podwozia samolotu B-767 

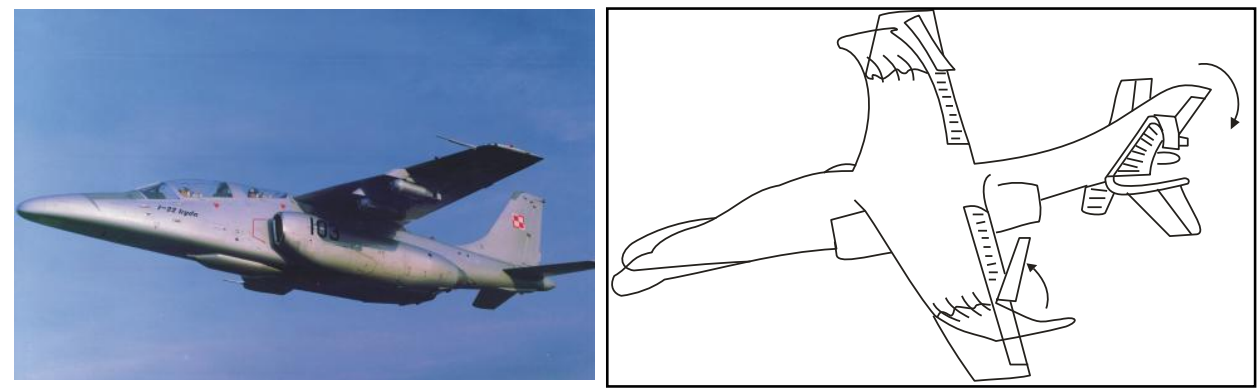

Rys. 7. Zniszczenia samolotu I-22 wywołane drganiami flatter

Uszkodzenie UT może wywołać człowiek. Na rysunku 8 pokazano przykład uszkodzenia UT zaczerpnięty z lotnictwa. W pewnym przedsiębiorstwie lotniczym samowolnie zmieniono procedurę smarowania usterzenia samolotu MD-83, co doprowadziło do zatarcia i unieruchomienia usterzenia w czasie lotu, w konsekwencji do katastrofy lotniczej (rys. 8).

Znane są liczne przykłady katastrof i awarii UT, których praprzyczyna tkwi w niedocenianiu warunków przyszłej eksploatacji, tak przez projektanta, konstruktora oraz technologa, załogę użytkującą UT, jak i naziemny personel techniczny [5].

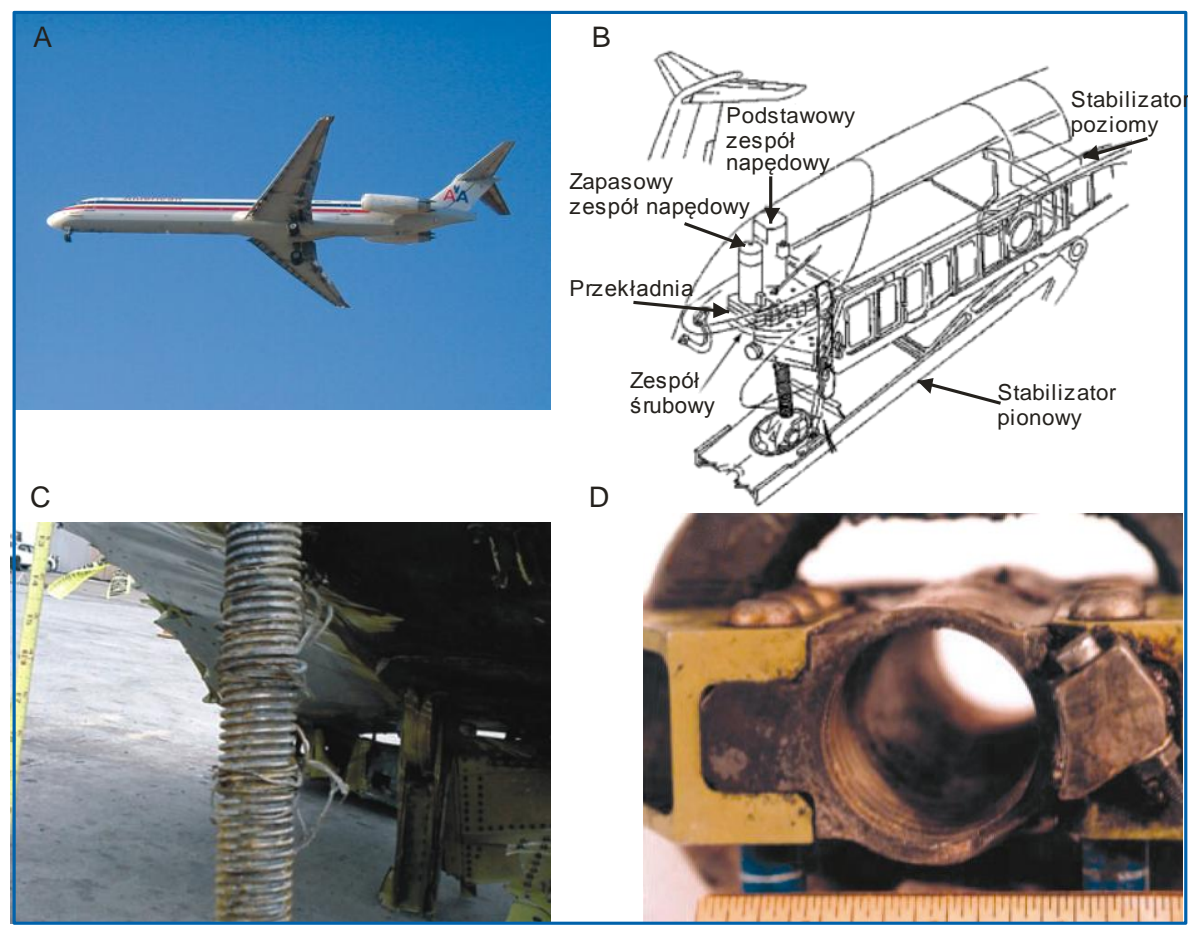

Rys. 8. Zatarcie mechanizmu usterzenia samolotu MD-83 


\section{Podsumowanie}

Nie wystarczy zaprojektowanie, skonstruowanie i wyprodukowanie nowoczesnego obiektu technicznego, urządzenia technicznego, o ile nie odpowie się z góry na pytanie ekonomiczno-strukturalne. Ile będzie kosztować eksploatacja? Jakiej wymagać będzie organizacji, jakiego oprzyrządowania i personelu do realizacji strukturalnych zadań w locie?

Projektowanie UT z uwzględnieniem wymagań: ekonomiczności, niezawodności, bezpieczeństwa, trwałości i innych atrybutów szeroko rozumianej eksploatacji stało się normą. Ale zawsze doświadczenia rzeczywistej eksploatacji będą nową inspiracją dla projektantów. Dlatego ważnym problemem jest przepływ informacji z doświadczeń eksploatacyjnych w kierunku projektantów, konstruktorów i technologów.

Konieczność modernizacji obiektów technicznych lub ich wymiana na nowe ujawnia się w procesie eksploatacji. Eksploatacja jest więc szczególnym etapem weryfikacji wszelkich tez twórczych i wytwórczych zrealizowanych w poprzednich fazach istnienia obiektów technicznych.

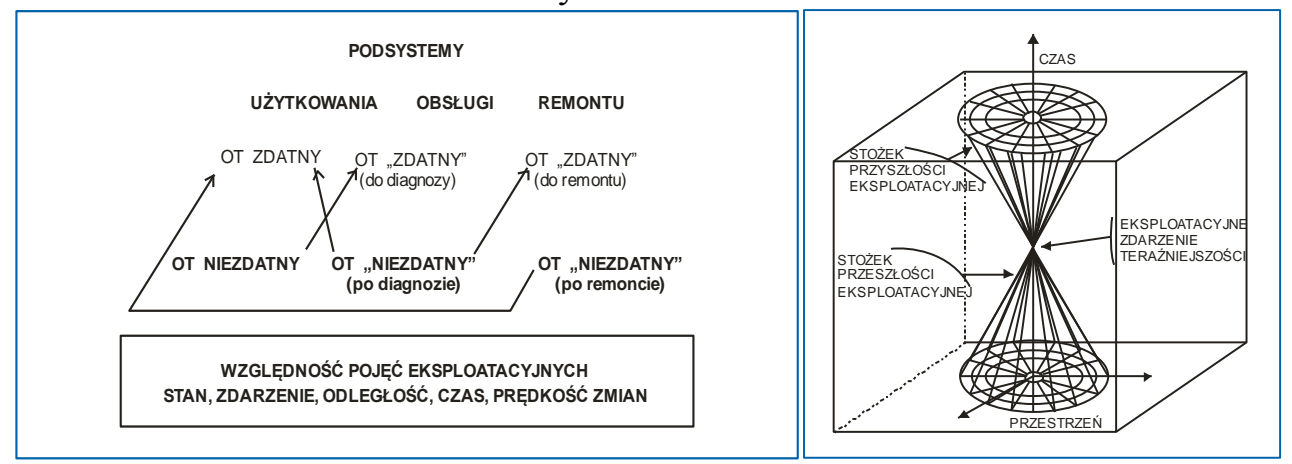

Rys. 9. Ilustracja względności pojęć eksploatacyjnych i stożek historii zdarzenia eksploatacyjnego

Pojęcie „eksploatacja obiektów technicznych” zawiera w sobie ogromny zasób znaczeń, przez co można powiedzieć, że jest interdyscyplinarne. Pod tym pojęciem rozumie się: naukę o eksploatowaniu UT jako budowę teoretycznych podstaw eksploatowania, wychodząc z uogólnionych praw teorii inżynierii eksploatacji zwanej eksploatyką, która bezpośrednio definiuje użyteczne zasady i metody, zapewniające realizacje zadań, do jakich zbudowane zostały obiekty techniczne. Eksploatacja UT musi być rozpatrywana w ujęciu czasoprzestrzennym, w całej swojej złożoności bezpiecznej, efektywnej i terminowej realizacji zadań z uwzględnieniem względności pojęć eksploatacyjnych i stożka historii zdarzeń eksploatacyjnych (rys. 9), co wynika z rozważań eksploatyki [2, 4].

Podsumowaniem powyższych naszkicowanych rozważań może być konkluzja, że: eksploatacja jest nauka zawierająca sztukę różnorodnych działań, jest filozofia skupiajaca wszystkie obszary wiedzy, a zatem powinna już zostać uznana za dyscyplinę naukowa. 


\section{Literatura}

[1] Ferguson N.: Civilization. The West and the Rest. Wydawnictwo Literackie. Warszawa 2013.

[2] Lewitowicz J.: Podstawy eksploatacji statków powietrznych - Statek powietrzny $i$ elementy teorii. Tom 1. Wydawnictwo ITWL. Warszawa 2001.

[3] Lewitowicz J.: Podstawy eksploatacji statków powietrznych - Systemy eksploatacji statków powietrznych. Tom 3. Wydawnictwo ITWL. Warszawa 2006.

[4] Lewitowicz J.: Problemy wspótczesnej teorii eksploatacji - eksploatyki. Problemy eksploatacji, 4 (59), 2005.

[5] Lewitowicz J.: Problems of failures of airplanes and helicopters. Journal of KONES Power and Transport, Vol. 14, No. 3, 2007.

[6] Stownik wyrazów obcych. PWN, Warszawa 1960.

[7] Stownik wyrazów obcych. PWN, Warszawa 1980.

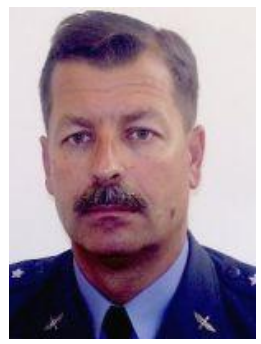

Gen. bryg. (rez.) pil. Stefan Rutkowski byty Szef Wojsk Lotniczych Zastępca - Szefa Szkolenia Sit Powietrznych. Pilot samolotów MiG - 29, spędzit w powietrzu około 2800 godzin. $W$ swojej karierze petnit wiele stanowisk dowódczych, studiowat równiez $w$ USA. Glówny obszar zainteresowań to wptyw szkolenia symulatorowego na bezpieczeństwo wykonywania zadań lotniczych.

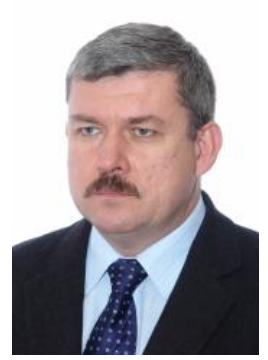

Mgr inz. Ryszard Tomaska - ukończyt studia w roku 1986 na Wydziale Mechanicznym Wojskowej Akademii Technicznej. Ponad 27 lat doświadczeń ze stużby w Silach Powietrznych na różnych stanowiskach zwiazanych $z$ utrzymaniem zdatności statków powietrznych. $W$ dorobku pięć publikacji naukowych oraz opracowania rozwiazań racjonalizatorskich. Aktualnie pracuje $w$ firmie BAE Systems $i$ jest specjalista do spraw programów lotniczych, wojskowych i systemów bezpieczeństwa. 


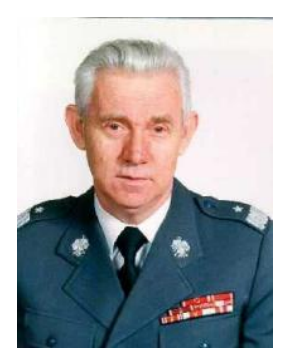

Prof. dr hab. inz. Jerzy Lewitowicz. Absolwent Wojskowej Akademii Technicznej $i$ Uniwersytetu Warszawskiego. Główne zainteresowania: rozwój najnowszej techniki wojskowej, w tym w szczególności lotniczej, budowa i eksploatacja samolotów $i$ śmigłowców ze szczególnym uwzględnieniem diagnostyki. Posiada ponad 50. letni staz naukowy i dydaktyczny w Instytucie Technicznym Wojsk Lotniczych i na Politechnice Warszawskiej. Jest czlonkiem SIMP, AIAA, ICAS. Wieloletni czlonek trzech komitetów Polskiej Akademii Nauk: Fizyki, Budowy Maszyn, Badań Kosmicznych i Satelitarnych. Autor licznych publikacji naukowych (ponad 400). Autor $i$ współautor 23 książek naukowych z dziedziny eksploatacji statków powietrznych, tribologii, diagnostyki, bezpieczeństwa lotów, licznych patentów oraz wzorów użytkowych. Posiada stopień wojskowy generata brygady (w rez.). Jest pracownikiem naukowym Instytutu Technicznego Wojsk Lotniczych.

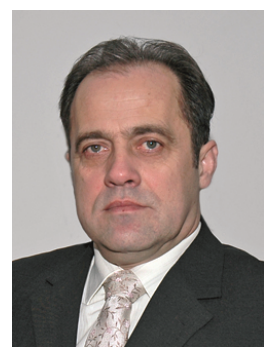

Prof. nadzw. dr hab. inż. Andrzej Żyluk. Absolwent wydzialu Elektro-mechanicznego Wojskowej Akademii Technicznej w 1985roku w dziedzinie konstrukcji i eksploatacji uzbrojenia lotniczego. Jest pracownikiem naukowym w ITWL ipetni obowiazki zastępcy dyrektora ds. naukowo-badawczych ITWL. $W$ dorobku naukowym posiada ponad 60 publikacji naukowych $z$ zakresu badań $i$ eksploatacji statków powietrznych, $w$ tym w szczególności systemów uzbrojenia lotniczego, badania wypadków lotniczych, modelowanie matematyczne systemów technicznych. Posiada stopień wojskowy podpułkownika w rezerwie. 